of this nature, answers to some of the following questions: What is the rate of oxygen uptake in any one particular animal ? How can this be measured? What environmental factors affect it ? Is oxygen uptake affected by the size of an animal ? How much more oxygen is required by active animals? Do animals living in habitats with low oxygen concentrations show any anatomical adaptations for increasing their oxygen uptake? What does the dissociation curve of a respiratory pigment look like ? None of these is dealt with. Yet these are surely just the kinds of question that the attention of the student should be drawn towards, and especially so in his seminars, his tutorials and his essay writing.

D. J. Aidley

\section{BIRD'S EGG CHEMISTRY}

\section{Biochemistry of the Avian Embryo}

A Quantitative Analysis of Prenatal Development. By Alexis L. Romanoff with the collaboration of Anastasia $\mathbf{J}$ Romanoff. Pp. xviii +398. (New York and London: Interscience Publishers, a division of John Wiley and Sons, 1967.) 156s.

Professor Romanoff has long been an authority on the development of the avian cmbryo, and this, his latest production, is a valuable book which every embryologist, once he has seen it, will wish to have for frequent reference. Compiled from an examination of more than 5,000 pertinent publications, the information is provided in an intelligible and palatable form, mostly by means of tables with adequate explanatory text and many figures. Equally important are the large number of references and more than twenty pages of bibliography, where the reader may find more details and be able to investigate the biochemistry of his problem in depth. Indeed, the book combines an introduction to chemical embryology and a reference manual for the advanced research worker in this field.

It should be emphasized, however, that it is not a discourse on the biochemical processes occurring in the avian embryo, nor does it deal with the problem of differentiation and intercellular reactions. On the contrary, it is more of an encyclopaedia of biochemical facts and figures relating to every component of intra- and extra-embryonic tissue or organ at frequent stages (usually every day) from the beginning of incubation to hatching. Even those who have ceased to marvel at the transformation of the contents of a bird's egg into an independent viable organism will learn a great deal to their advantage and be grateful to the authors for the labour of collecting so much and presenting it in so little space.

It is with my tongue in my cheek that I direct attention to page 122 where the total blood volume within the chick egg on the eighteenth day is reported as reaching its peak of $2,900 \mathrm{ml}$. Reference to the accompanying tables soon reveals that $2,900 \mathrm{~mm}^{3}$ is the intention-a more acceptable figure.

JoHN McKENZIE
Cleaver's monograph deals specifically with work done using tritium $\left(\mathrm{H}_{3}\right)$ labelled thymidine, a unique compound that is almost exclusively incorporated into cell DNA and therefore makes possible very specific marking of this important macromolecule. Possible uses which come to mind are studies of DNA replication, chromosome and nuclear distribution, the cell cycle and population kinetics. Early chapters in the book discuss methods of preparation and detection of the compound, as well as what is known about thymidine metabolism in various types of cell. Experimental details are generally not included (they would, in any case, make the book unnecessarily complicated), but this is compensated for by a comprehensive bibliography. The use of tritiated thymidine in following events during the cell cycle occupies the larger part of the book, including a treatise on the kinetics of defined cell populations. The text is well supplemented with simplified diagrams, and those less mathomatically minded are spared the complicated theory and assump. tions involved in the use of radioactive thymidine until a final appendix.

Dr Cleaver is mainly concerned with mammalian cells, but does not ignore the results obtained from microorganisms, plants and insects. Such cell types especially have contributed to our knowledge of chromosome replication, the segregation patterns of chromatids after mitosis, and of cross-overs during meiosis. In treating the cell cycle, the various phases of which are usually represented schematically by sectors on a clock face, the mammalian cell is used almost exclusively as a modol. A large number of different cell types have now been characterized with respect to the duration of each part of the cycle, both in vitro and in vivo, and it is of interest that the $G_{1}$ phase (between mitosis and DNA synthesis) has greater variability between different cell types than either the DNA replication phase $(S)$ or the period following replication $\left(G_{2}\right)$. The commonly held fallacy that tumour cells have a higher growth rate than nonmalignant cells was exposed as such by comparing the respective cell cycles.

In writing the book, Dr Cleaver has assumed the reader to have a certain fundamental knowledge of the Watson and Crick hypothesis, the mitotic cycle, and of the basic organization of cell nuclei. The application of tritiated thymidine to such problems, however, is fully discussed. Though our understanding of chromosome structure and its mode of replication in diploid cells is less precisely known than in haploid unicellular organisms, models based on the latter are suggested for the more advanced cell types.

The index might usefully have included those authors mentioned in the text. It may also be that the immunologist will be a little hurt that the interesting mitotic events following antigenic challenge have been largely ignored. These, however, are minor criticisms, and research workers in any way involved in the study of nuclear DNA are likely to find the monograph of invaluable assistance and a useful reference source.

\section{A. J. S. Davies}

\title{
THYMIDINE IN CELLS
}

\section{Thymidine Metabolism and Cell Kinetics}

By J. E. Cleaver. (North-Holland Research Monographs: Frontiers of Biology. Vol. 6.) Pp. 259. (Amsterdam: North-Holland Publishing Company, 1967.) $86 s$.

THE introduction of the radioactive isotopes of carbon, phosphorus, sulphur and hydrogen into the biological sciences during the past two decades has permitted great advances in our understanding of the structure and function of living matter. A significant factor in their use is that they can be incorporated by living tissues without giving rise to excessive disruption of metabolic processes by virtue of their radioactivity.

\section{NON ANGELI SED AVES}

\section{Radar Ornithology}

By Eric Eastwood. Pp. xii $+278+24$ plates. (London: Methuen and Co., Ltd., 1967.) 75s. net.

To speak of a new science, as does the author, is surely an enthusiastic exaggeration. A new technique has certainly been exploited in the past dozen years by those ornithologists who parasitically battened on to earlywarning or airport radars. It now has such an accepted place in bird migration studies that it is hard to appreciate the difficulties early users had in convincing radar technicians that many anomalous echoes on their screens, 